\title{
Genetic Analysis and Molecular Mapping of Wheat Genes Conferring Resistance to the Wheat Stripe Rust and Barley Stripe Rust Pathogens
}

\author{
Vihanga Pahalawatta and Xianming Chen
}

\begin{abstract}
First and second authors: U.S. Department of Agriculture-Agricultural Research Service, Wheat Genetics, Quality, Physiology, and Disease Research Unit, and Department of Plant Pathology, Washington State University, Pullman 99164; and PNNS 0384, College of Agriculture Research Center, Washington State University, Pullman 99164.
\end{abstract} Accepted for publication 13 December 2004.

ABSTRACT

\begin{abstract}
Pahalawatta, V., and Chen, X. M. 2005. Genetic analysis and molecular mapping of wheat genes conferring resistance to the wheat stripe rust and barley stripe rust pathogens. Phytopathology 95:427-432.

Stripe rust is one of the most important diseases of wheat and barley worldwide. On wheat it is caused by Puccinia striiformis f. sp. tritici and on barley by $P$. striiformis f. sp. hordei. Most wheat genotypes are resistant to P. striiformis f. sp. hordei and most barley genotypes are resistant to $P$. striiformis $\mathrm{f}$. sp. tritici. To determine the genetics of resistance in wheat to $P$. striiformis f. sp. hordei, crosses were made between wheat genotypes Lemhi (resistant to P. striiformis f. sp. hordei) and PI 478214 (susceptible to $P$. striiformis $\mathrm{f}$. sp. hordei). The greenhouse seedling test of $150 \mathrm{~F}_{2}$ progeny from the Lemhi $\times$ PI 478214 cross, inoculated with race PSH-14 of $P$. striiformis $\mathrm{f}$. sp. hordei, indicated that Lemhi has a dominant resistance gene. The single dominant gene was confirmed by testing seedlings of the $\mathrm{F}_{1}, \mathrm{BC}_{1}$ to the two parents, and $150 \mathrm{~F}_{3}$ lines from the $\mathrm{F}_{2}$ plants with the same race. The tests of the $\mathrm{F}_{1}, \mathrm{BC}_{1}$, and $\mathrm{F}_{3}$ progeny with race PSH-48 of $P$. striiformis f. sp. hordei and PST-21 of P. striifor-
\end{abstract}

mis f. sp. tritici also showed a dominant gene for resistance to these races. Cosegregation analyses of the $\mathrm{F}_{3}$ data from the tests with the two races of $P$. striiformis f. sp. hordei and one race of $P$. striiformis f. sp. tritici suggested that the same gene conferred the resistance to both races of P. striiformis f. sp. hordei, and this gene was different but closely linked to $Y r 21$, a previously reported gene in Lemhi conferring resistance to race PST-21 of $P$. striiformis f. sp. tritici. A linkage group consisting of 11 resistance gene analog polymorphism (RGAP) markers was established for the genes. The gene was confirmed to be on chromosome $1 \mathrm{~B}$ by amplification of a set of nullitetrasomic Chinese Spring lines with an RGAP marker linked in repulsion with the resistance allele. The genetic information obtained from this study is useful in understanding interactions between inappropriate hosts and pathogens. The gene identified in Lemhi for resistance to $P$. striiformis f. sp. hordei should provide resistance to barley stripe rust when introgressed into barley cultivars.

Additional keywords: Hordeum vulgare, Triticum aestivum.
Stripe rust, caused by Puccinia striiformis Westend., is an important disease of wheat (Triticum aestivum L.) and barley (Hordeum vulgare L. emend. Bowden) in most regions of the world (41). Stripe rust of wheat was first recognized in the United States in 1915 (25); however, stripe rust of barley had not been reported in the United States until 1991 (39). Barley stripe rust is now well established and destructive in the western United States, and sometimes causes damage in south-central states $(3,8)$, while wheat stripe rust occurs everywhere in the U.S. mainland except northeastern states and causes severe damage in western, central, south-central, and southeastern states (11-13).

Eriksson (16) subdivided $P$. striiformis (referred to as $P$. glumarum) into formae speciales based on their host ranges. Stripe rust of wheat is caused by $P$. striiformis f. sp. tritici and stripe rust of barley by P. striiformis f. sp. hordei. Newton (35) demonstrated that $P$. striiformis f. sp. tritici and hordei differed in isozyme mobility for two enzymes on starch gels and in the banding pattern of double-stranded RNA (dsRNA) molecules on polyacrylamide gels, whereas isolates within a forma specialis were uniform in their isozyme mobility. Chen et al. (8), using random amplified polymorphic DNA (RAPD), demonstrated that the two formae speciales clearly are different but more closely related to each

Corresponding author: X. M. Chen; E-mail address: xianming@mail.wsu.edu

DOI: 10.1094/PHYTO-95-0427

This article is in the public domain and not copyrightable. It may be freely reprinted with customary crediting of the source. The American Phytopathological Society, 2005. other than to $P$. striiformis f. sp. poae, causing stripe rust on bluegrass. However, the two formae speciales have overlapping host ranges, although $P$. striiformis f. sp. tritici seldom causes damage on barley and $P$. striiformis f. sp. hordei seldom causes damage on wheat. Before P. striiformis f. sp. hordei was introduced to North America, stripe rust found on barley plants always was identified as $P$. striiformis $\mathrm{f}$. sp. tritici, but never caused significant damage (25). Studies evaluating germ plasm lines of wheat and barley showed that most barley cultivars are resistant to $P$. striiformis $\mathrm{f}$. sp. tritici and that most wheat cultivars are resistant to $P$. striiformis f. sp. hordei (8).

Among the methods available for controlling stripe rust, growing resistant cultivars is the most efficient, economically viable, and environmentally friendly approach to control the disease (26). More than 30 genes in wheat for resistance to $P$. striiformis f. sp. tritici have been officially named and numerous genes have been assigned temporary designations $(10,33)$. However, cultivars with resistance conferred by a single gene often lose their resistance due to the appearance of new virulent races of the pathogen with the ability to circumvent the resistance $(12,27,41)$. Therefore, scientists have turned to alternative sources of resistance that can be transferred to cereal crops $(21,32,33)$. Genes from an inappropriate host may provide a potential source of resistance for breeding programs.

Most genes conferring resistance to pathogens have common motifs, such as leucine-rich repeats (LRR), nucleotide-binding sites (NBS), and kinase domains. DNA sequences amplified by degenerate primers based on these conserved motifs are known as resistance gene analogs (RGAs). RGAs have been used to isolate plant resistance genes and develop molecular markers $(18,20$, 
24,47). The RGA approach was improved further by Chen et al. (9) and the technique was referred to as resistance gene-analog polymorphism (RGAP) $(1,40)$. The RGAP technique has been used to develop molecular markers for genes in wheat conferring resistance to wheat stripe rust $(40,46)$, and for genes in barley conferring resistance to barley stripe rust, barley leaf rust, scald, net blotch, barley yellow dwarf, and scab $(5,9,42)$. The RGAP technique could be useful in identification of markers for genes conferring resistance to inappropriate pathogens.

The initial goal of a series of studies was to understand the genetic interactions between the two stripe rust formae speciales virulent on wheat and barley and the inappropriate hosts, barley and wheat. The objectives of the present study were to determine inheritance of wheat resistance to the inappropriate pathogen, $P$. striiformis f. sp. hordei; to determine the genetic relationship between wheat genes conferring resistance to the $P$. striiformis f. sp. tritici appropriate pathogen and the P. striiformis f. sp. hordei inappropriate pathogen; and to map wheat genes conferring resistance to barley stripe rust using the RGAP technique.

\section{MATERIALS AND METHODS}

Plant materials. Crosses were made between spring wheat genotypes Lemhi (CI 11415) and PI 478214. The wheat cv. Lemhi is highly susceptible to all races, except for race PST-21, of $P$. striiformis f. sp. tritici identified so far in the United States (12; X. M. Chen, unpublished data) but highly resistant to all tested races of $P$. striiformis f. sp. hordei (8). Originally from Ethiopia, the wheat genotype PI 478214 is susceptible to all tested races of $P$. striiformis f. sp. tritici and hordei (8). Lemhi was crossed with PI 478214 in the greenhouse. Three to five $F_{1}$ seed from different crossed heads were planted in the greenhouse for making backcrosses and for selfing to produce $\mathrm{F}_{2}$ seed. Backcrosses were made to both parents using the $F_{1}$ plants as the female parent. $F_{2}$ seed were planted in the greenhouse for DNA isolation, stripe rust testing, and $\mathrm{F}_{3}$ seed. Leaves of each parent and 150 individual $F_{2}$ plants were cut for DNA extraction and the plants were allowed to grow again. $F_{3}$ seed harvested from the 150 individual $F_{2}$ plants were used for stripe rust tests.

Pathogen materials. Single pustule isolates were obtained for race PST-21 of $P$. striiformis f. sp. tritici and races PSH-14 and PSH-48 of P. striiformis f. sp. hordei. Race PST-21 is virulent only on Chinese $166(\mathrm{Yrl})$ among the 20 wheat genotypes that are used to differentiate races of $P$. striiformis f. sp. tritici (12). In addition, PST-21 also is virulent on susceptible wheat cultivars such as Nugaines and Michigan Amber. Race PSH-48 is virulent only on one barley genotype (Topper), whereas PSH-14 is virulent on 8 (Topper, Heils Franken, Emir, Astrix, Hiproly, Varunda, Abed Binder 12, and Trumpf) of the 12 barley genotypes that are used to differentiate races of $P$. striiformis $\mathrm{f}$. sp. hordei $(4,8)$. The single-pustule isolate of PST-21 was tested on wheat differentials and those of PSH-14 and PSH-48 were tested on barley differentials to confirm their avirulent or virulent infection types. Urediniospores of the single-pustule isolates were collected and tested on the wheat differential set for PST-21 and the barley differential set for PSH-14 and PSH-48 to confirm purity of isolates. Pure urediniospore isolates were increased on susceptible differential cultivars and used to evaluate stripe rust resistance of the parents and progeny of the Lemhi $\times$ PI 478214 cross.

Evaluation for stripe rust resistance. The $150 \mathrm{~F}_{2}$ plants that had been used for DNA extraction were inoculated with urediniospores of race PSH-14 when the plants were in the boot stage. Seedling tests also were performed for parents, $\mathrm{F}_{1}, \mathrm{BC}_{1}$, and $\mathrm{F}_{3}$, progeny using races PSH-14, PSH-48, and PST-21. In all, 6 to 10 seedlings of each parent, 3 to 5 seedlings of $F_{1}, 35$ to 45 seedlings of each of the $\mathrm{BC}_{1}$ to the parents, and 10 to 15 seedlings of each of the $150 \mathrm{~F}_{3}$ lines were used for evaluating stripe rust resistance. All seedlings were grown in a rust-free greenhouse at a diurnal temperature cycle of 10 to $25^{\circ} \mathrm{C}$. Metal halide lights were used before and after inoculation to maintain an 8-h dark and 16-h photoperiod. At the two-leaf stage, seedlings were uniformly inoculated with urediniospores of a test race. Inoculated plants were placed in a dew chamber at $10^{\circ} \mathrm{C}$ for $24 \mathrm{~h}$. Seedlings then were moved to a growth chamber at temperatures programmed to change gradually between a minimum of 2 to $5^{\circ} \mathrm{C}$ at 2:00 a.m. during the 8 -h dark period and a maximum of 18 to $20^{\circ} \mathrm{C}$ at 2:00 p.m. during the 16-h light period (2). Infection type (IT) data were recorded based on the 0 -to- 9 scale at 18 and 21 days after inoculation (28). Infection types 0 to 3,4 to 6 , and 7 to 9 were considered to be resistant, intermediate, and susceptible reactions, respectively.

DNA extraction, polymerase chain reaction amplification, electrophoresis, and gel visualization. Fresh leaves $(3 \mathrm{~g})$ from individual $F_{2}$ plants and the parental genotypes were ground in liquid nitrogen. DNA was extracted from the leaf powder following the protocol described by Riede and Anderson (38). The extracted DNA was dissolved in $1 \times$ Tris-EDTA (TE) buffer $(10 \mathrm{mM}$ Tris- $\mathrm{HCl}$ and $1 \mathrm{mM}$ EDTA, $\mathrm{pH} 8.0$ ), and stored at $-20^{\circ} \mathrm{C}$. DNA was quantified using the mini-gel method (30) and spectrophotometer (Smartspec 3000; Bio-Rad, Hercules, CA) and the concentration was adjusted to $30 \mathrm{ng} / \mu \mathrm{l}$. The RGAP protocol described by Chen et al. (9) was used in this study. Modifications to the reaction volume and component concentrations described by Yan et al. (46) were applied. Forty-eight primers were designed based on conserved motifs of cloned resistance genes $(9,40,46)$ and synthesized by Operon (Alameda, CA). Polymerase chain reaction (PCR) amplification was performed in a DNA thermocycler (Perkin-Elmer, San Diego, CA) programmed for $5 \mathrm{~min}$ at $94^{\circ} \mathrm{C}$ for initial denaturation and 45 cycles each consisting of $1 \mathrm{~min}$ at $94^{\circ} \mathrm{C}, 1 \mathrm{~min}$ at $45^{\circ} \mathrm{C}$, and $2 \mathrm{~min}$ at $72^{\circ} \mathrm{C}$, followed by a final extension for $7 \mathrm{~min}$ at $72^{\circ} \mathrm{C}$. A 2.5 -min ramp time was used between the $94^{\circ} \mathrm{C}$ denaturation and the $45^{\circ} \mathrm{C}$ annealing steps. The fastest possible ramp was employed for all other temperature transitions.

The success of the amplification was checked by electrophoresing the PCR product in a $1 \%$ agarose gel. Formamide loading buffer $(6 \mu \mathrm{l} ; 98 \%$ formamide, $10 \mathrm{mM}$ EDTA [pH 8.0], $0.5 \%$ [wt/vol] bromophenol blue, and $0.5 \%$ [wt/vol] xylene cyanol) was added to the PCR product and mixed prior to loading $(4 \mu \mathrm{l})$ the agarose gel.

Amplified DNA fragments were separated in a 5\% denaturing polyacrylamide gel (398 by 338 by $0.4 \mathrm{~mm}$ ), prepared according to manufacturer specifications. The gel was allowed to polymerize for $2 \mathrm{~h}$ and pre-run in $1 \times$ Tris-borate-EDTA (TBE) buffer (90 mM Tris-borate, $2 \mathrm{mM}$ EDTA [pH 8.0]) for 30 to $40 \mathrm{~min}$ at $1,600 \mathrm{~V}$, until the gel temperature reached $\approx 50^{\circ} \mathrm{C}$. PCR samples were denatured at $94^{\circ} \mathrm{C}$ for $3 \mathrm{~min}$ and 6 to $8 \mu$ of the sample was loaded into the wells. The loaded gel was run at $1,350 \mathrm{~V}$ for 3 to $3.5 \mathrm{~h}$, depending on the approximate size of the bands of interest. The gel was silver stained according to the manufacturer's recommendation (Promega Corp., Madison, WI) and allowed to dry overnight at room temperature. Silver-sequence automatic processor compatible film (Promega-Corp.) was used to produce a photograph of the gel.

Genomic DNA samples from Lemhi, PI 478214, and two DNA bulks of $\mathrm{F}_{2}$ progeny were used for screening primers. The two DNA bulks consisted of equal amounts of DNA from 10 homozygous resistant and 10 homozygous susceptible $F_{2}$ plants that were confirmed by testing the $\mathrm{F}_{3}$ progeny. Polymorphic RGAP bands specific to Lemhi and the resistant bulk were tested further in the $F_{2}$ population, consisting of 150 progeny. The association between polymorphic RGAP markers and stripe rust reactions was determined through linkage analysis. Chromosomal location of $Y r 21$ for resistance to $P$. striiformis f. sp. tritici and the gene for resistance to $P$. striiformis $\mathrm{f}$. sp. hordei was determined by analyzing the set of 21 Chinese Spring nullitetrasomic lines and 
disomic Chinese Spring with a marker linked in repulsion to the resistance genes.

Data analyses. To determine the goodness of fit of the observed compared with predicted segregation ratios of the $\mathrm{F}_{2}$ and $\mathrm{F}_{3}$ progeny to establish the number of stripe rust resistance genes, dominance or recessiveness of resistance, and relationships of genes for resistance to different races, $\chi^{2}$ tests were used. Linkage analyses and map construction of RGAP markers and the resistance loci were performed with the computer program Mapmaker (version 3.0) (23). A $\log$ of the likelihood score of 3.0 and Kosambi's mapping function (22) were used to establish the linkage.

\section{RESULTS}

Genetic and phenotypic analyses. The observed number and expected ratios of resistant (IT 0 to 3 ) and susceptible (IT 7 to 9) plants for parents, $\mathrm{F}_{1}, \mathrm{~F}_{2}, \mathrm{BC}_{1}$, and $\mathrm{F}_{3}$ progeny inoculated with races $\mathrm{PSH}-14$ and $\mathrm{PSH}-48$ of $P$. striiformis $\mathrm{f}$. sp. hordei and race PST-21 of $P$. striiformis $\mathrm{f}$. sp. tritici, and probabilities of $\chi^{2}$ tests for goodness of fit, are shown in Table 1. Races PSH-14, PSH-48, and PST-21 produced IT 1 on Lemhi and IT 9 on PI 478214. All $\mathrm{F}_{1}$ plants had IT 1 in all three race tests. When inoculated with race $\mathrm{PSH}-14$, the $\mathrm{F}_{2}$ seedlings segregated in a ratio of three resistant to one susceptible, indicating a single dominant gene in Lemhi for resistance to PSH-14. $\mathrm{F}_{3}$ lines derived from the $\mathrm{F}_{2}$ progeny segregated in a ratio of $1: 2: 1$ resistant/segregating/ susceptible when inoculated with PSH-14 and PSH-48, confirming the presence of a single dominant gene for resistance to both races. Furthermore, there was no difference in reaction categories (homozygous resistant, segregating, and homozygous susceptible) for the $\mathrm{F}_{3}$ lines inoculated with the two PSH races. These results show that the resistance to both races is controlled by the same gene. All $\mathrm{F}_{3}$ lines derived from susceptible $\mathrm{F}_{2}$ progeny were susceptible, indicating that the susceptible $\mathrm{F}_{2}$ plants were homozygous and the susceptibility was recessive. The segregations of the backcross to PI 478214 tested with both PSH-14 and PSH-48 fits a 1:1 ratio for resistant and susceptible plants. All plants of the backcross to Lemhi were resistant. The results further confirmed a single dominant gene in Lemhi conferring resistance to both PSH14 and PSH-48.
When tested with race PST-21 of $P$. striiformis f. sp. tritici, resistant reaction (IT 1) of the $F_{1}$ progeny and segregation ratios of $\mathrm{F}_{2}, \mathrm{BC}_{1}$, and $\mathrm{F}_{3}$ generations of the Lemhi $\times$ PI 478214 cross confirmed a dominant gene, $\operatorname{Yr} 21$, for resistance to the wheat stripe rust race (6). The relationship between the gene in Lemhi conferring resistance to $\mathrm{PSH}$ races and $\mathrm{Yr} 21$ conferring resistance to PST-21 was determined by joint analysis of reaction categories for the $\mathrm{F}_{3}$ lines inoculated with race PST-21 and races PSH-14 and PSH-48 (Table 2). The results for the $\chi^{2}$ test $(P<0.001)$ indicate that the gene for resistance to the PSH races is not independent of $Y r 21$. There were no $\mathrm{F}_{3}$ lines with a resistant reaction to both PSH-14 and PSH-48 that showed a susceptible reaction to PST-21. Similarly, there were no $F_{3}$ lines with a susceptible reaction to both PSH-14 and PSH-48 that showed a resistant reaction to PST-21. The results indicated that Lemhi had either a single gene for resistance to race PST-21 of $P$. striiformis f. sp. tritici and races PSH-14 and PSH-48 of P. striiformis f. sp. hordei, or it had two closely linked genes each conferring resistance to one of the formae speciales. Two of the $150 \mathrm{~F}_{3}$ lines were homozygous resistant to PSH-14 and $\mathrm{PSH}-48$, but segregated when tested with PST-21; one of the lines was homozygous resistant to PSH-21, but segregated when tested with PSH-14 and PSH-48; and one of the lines was susceptible to PST-21, but segregated when tested with PSH-14 and PSH-48. These lines were tested at least twice to confirm the reactions to different races. The results indicate that the gene conferring resistance to PSH-14 and PSH-48 is different from but closely linked to $\mathrm{Yr} 21$. To further confirm this result, one susceptible plant from $\mathrm{F}_{3}$ line 2, which was homozygous resistant to $\mathrm{PSH}-14$ but segregating to PST-21, was transplanted to grow for $\mathrm{F}_{4}$ seed after being tested with PST-21. The single-seed descent $\mathrm{F}_{4}$ line was homozygous resistant to PSH-14 but homozygous susceptible to PST-21. Similarly, an $\mathrm{F}_{4}$ line from a PST-21-susceptible plant of $\mathrm{F}_{3}$ line 32, which also was homozygous resistant to PST-14 but segregating to PST-21, was homozygous resistant to PSH-14 but homozygous susceptible to PST-21. The data clearly showed that resistances to PSH-14 and PST-21 are controlled by two different genes.

RGAP markers associated with genes for resistance to races of $\boldsymbol{P}$. striiformis f. sp. hordei and $\boldsymbol{P}$. striiformis f. sp. tritici. In all, 390 pairs from 48 RGA primers were screened for bulk segregant analysis. Ten primer pairs that produced 11 repeatable polymor-

TABLE 1. Observed and expected phenotypic ratios of resistant (Res), segregating (Seg), and susceptible (Sus) plants in parents and $\mathrm{F}_{1}, \mathrm{~F}_{2}, \mathrm{BC}_{1}$, and $\mathrm{F}_{3}$ progeny of the cross Lemhi $\times$ PI 478214 inoculated with races PSH-14 and PSH-48 of Puccinia striiformis f. sp. hordei and race PST-21 of P. striiformis f. sp. tritici and probabilities of $\chi^{2}$ tests for goodness of fit

\begin{tabular}{|c|c|c|c|c|c|c|c|}
\hline \multirow[b]{2}{*}{ Race, generation } & \multicolumn{3}{|c|}{ Observed no. of plants/lines } & \multicolumn{3}{|c|}{ Expected ratio } & \multirow[b]{2}{*}{$P$} \\
\hline & Res & Seg & Sus & Res & Seg & Sus & \\
\hline \multicolumn{8}{|l|}{ PSH-14 } \\
\hline $\mathrm{P}_{1}$-Lemhi & 6 & $\ldots$ & 0 & 1 & $\ldots$ & 0 & $\ldots$ \\
\hline $\mathrm{P}_{2}$-PI 478214 & 0 & $\ldots$ & 6 & 0 & $\ldots$ & 1 & $\ldots$ \\
\hline $\mathrm{F}_{1}$ & 4 & $\ldots$ & 0 & 1 & $\ldots$ & 0 & $\ldots$ \\
\hline $\mathrm{F}_{2}$ & 120 & $\ldots$ & 30 & 3 & $\ldots$ & 1 & 0.16 \\
\hline $\mathrm{BC}_{1}$-Lemhi & 35 & $\ldots$ & 0 & 1 & $\ldots$ & 0 & $\ldots$ \\
\hline $\mathrm{BC}_{1}$-PI 478214 & 17 & $\ldots$ & 23 & 1 & $\ldots$ & 1 & 0.34 \\
\hline $\mathrm{F}_{3}$ & 42 & 67 & 35 & 1 & 2 & 1 & 0.50 \\
\hline \multicolumn{8}{|l|}{ PSH-48 } \\
\hline $\mathrm{P}_{1}$-Lemhi & 6 & $\ldots$ & 0 & 1 & $\ldots$ & 0 & $\ldots$ \\
\hline $\mathrm{P}_{2}$-PI 478214 & 0 & $\ldots$ & 6 & 0 & $\ldots$ & 1 & $\ldots$ \\
\hline$F_{1}$ & 5 & $\ldots$ & 0 & 1 & $\ldots$ & 0 & $\ldots$ \\
\hline $\mathrm{BC}_{1}$-Lemhi & 38 & $\ldots$ & 0 & 1 & $\ldots$ & 0 & $\ldots$ \\
\hline $\mathrm{BC}_{1}$-PI 478214 & 15 & $\ldots$ & 20 & 1 & $\ldots$ & 1 & 0.40 \\
\hline $\mathrm{F}_{3}$ & 42 & 69 & 33 & 1 & 2 & 1 & 0.50 \\
\hline \multicolumn{8}{|l|}{ PST-21 } \\
\hline $\mathrm{P}_{1}$-Lemhi & 7 & $\ldots$ & 0 & 1 & $\ldots$ & 0 & $\ldots$ \\
\hline $\mathrm{P}_{2}$-PI 478214 & 0 & $\ldots$ & 6 & 0 & $\ldots$ & 1 & $\ldots$ \\
\hline $\mathrm{F}_{1}$ & 5 & $\ldots$ & 0 & 1 & $\ldots$ & 0 & $\ldots$ \\
\hline $\mathrm{BC}_{1}$-Lemhi & 40 & $\ldots$ & 0 & 1 & $\ldots$ & 0 & $\ldots$ \\
\hline $\mathrm{BC}_{1}$-PI 478214 & 20 & $\ldots$ & 25 & 1 & $\ldots$ & 1 & 0.46 \\
\hline $\mathrm{F}_{3}$ & 44 & 73 & 28 & 1 & 2 & 1 & 0.17 \\
\hline
\end{tabular}


phic bands differentiating Lemhi and the resistant bulk from PI 478214 and the susceptible bulk were selected for co-segregation analysis using $150 \mathrm{~F}_{2}$ progeny. All identified RGAP markers were dominant. The 15 primers that produced polymorphic bands linked to the resistance loci are shown in Table 3. The fragment sizes and primer pairs of the 11 RGAP markers are shown in Table 4 . The bulk segregant analysis with the resistant parent, resistant bulk, susceptible parent, and susceptible bulk are shown in Figure 1 , and an example of the banding pattern of a set of $F_{2}$ progeny screened with RGA primer pair Pto kin3/XLRR-For is shown in Figure 2. The RGAP markers were linked to the resistance gene with a genetic distance ranging from 2.9 to 29.4 centimorgans (cM) (Fig. 3).

Tests were carried out on the 21 nullitetrasomic lines of Chinese Spring with RGA primer pair NLRR-Rev/S2 that was linked to the susceptibility allele at a distance of $29.2 \mathrm{cM}$. The unique band was detected in all lines except the NT1B/1A. These results show that the marker, together with other RGAP markers linked with $Y r 21$ for resistance to race PST-21 of $P$. striiformis f. sp. tritici and the gene in Lemhi for resistance to $P$. striiformis f. sp. hordei, is on chromosome 1B.

\section{DISCUSSION}

The results of this study showed a single resistance gene in wheat $\mathrm{cv}$. Lemhi conferring resistance to $P$. striiformis $\mathrm{f}$. sp. hordei races $\mathrm{PSH}-14$ and $\mathrm{PSH}-48$. Because $\mathrm{PSH}-48$ has the narrowest virulence spectrum and $\mathrm{PSH}-14$ is one of the races with the widest virulence spectrum, the same Lemhi gene may be effective against all other races of $P$. striiformis f. sp. hordei. In contrast to its resistance against all tested races of $P$. striiformis $\mathrm{f}$. sp. hordei (8), the wheat cv. Lemhi is susceptible to all races of
P. striiformis f. sp. tritici except PST-21 $(2,14)$. Race PST-21 is virulent only on Chinese $166(Y r l)$ of the North American, World, and European differentials and other susceptible wheat cultivars (29). Results of RAPD and virulence analyses suggest that race PST-21 has a source of origin different from other PST races (7). Comparison of isozyme assays of race PST-21 and a few other races also supported this hypothesis (29). According to Line and Qayoum (29), race PST-21 first was detected in an area where stripe rust commonly occurs on wild Hordeum spp. This may be the reason that, although Lemhi is an inappropriate host for

TABLE 4. Resistance gene-analog polymorphism (RGAP) markers for the gene conferring resistance to Puccinia striiformis f. sp. hordei in wheat cv. Lemhi, primers used to identify the marker, and the size of the markers ${ }^{\mathrm{a}}$

\begin{tabular}{llccc}
\hline & & & $\begin{array}{c}\text { Presence }(+) \text { or absence } \\
(-) \text { in the parents }\end{array}$ \\
\cline { 3 - 5 } RGAP marker & \multicolumn{1}{c}{ Primer pair ${ }^{\text {b }}$} & Size (bp) & Lemhi & PI 478214 \\
\hline M1 & Pto kin2/S2 & 256 & + & $\ldots$ \\
M2 & Pto kin3/PtoFen-S & 310 & + & $\ldots$ \\
M3 & LM637/Pto kin3 & 336 & + & $\ldots$ \\
M4 & Cre3Ploop/CLRR Rev & 310 & + & $\ldots$ \\
M5 & Pto kin3/XLRR For & 325 & + & $\ldots$ \\
M6 & OPF-14/RLK-For & 270 & + & $\ldots$ \\
M7 & S2-INV/AS3 & 258 & + & $\ldots$ \\
M8 & S2/AS1 & 338 & + & $\ldots$ \\
M9 & OPF-14/RLK-For & 264 & + & $\ldots$ \\
M10 & NLRR Rev/S2 & 248 & $\ldots$ & + \\
M11 & RLRR Rev/LM638 & 268 & + & $\ldots$ \\
\hline
\end{tabular}

a Sizes of the markers were estimated based on the 1-kb-plus molecular size marker.

${ }^{\mathrm{b}} \mathrm{OPF}-14$ is a random amplified polymorphic DNA primer (5'-TGCTGCAGGT-3').

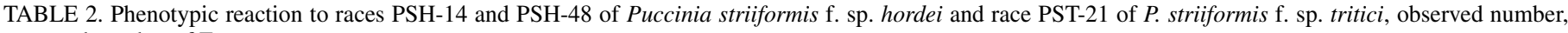
expected number of $F_{3}$ families based on a two-gene model, and proposed $F_{2}$ genotype of the cross Lemhi $\times$ PI 478214

\begin{tabular}{|c|c|c|c|c|c|}
\hline \multicolumn{2}{|c|}{ Phenotype } & \multirow[b]{2}{*}{ Observed no. of $\mathrm{F}_{3}$ lines } & \multicolumn{2}{|c|}{ Expected $\mathrm{F}_{3}$ lines } & \multirow[b]{2}{*}{ Proposed $\mathrm{F}_{2}$ genotype } \\
\hline PSH-14 or PSH-48 & PST-21 & & Ratio & Number & \\
\hline Resistant & Resistant & 39 & 1 & 9.06 & AABB \\
\hline Resistant & Segregating & 3 & 2 & 18.13 & $\mathrm{AABb}$ \\
\hline Resistant & Susceptible & 0 & 1 & 9.06 & AAbb \\
\hline Segregating & Resistant & 5 & 2 & 18.13 & $\mathrm{AaBB}$ \\
\hline Segregating & Segregating & 61 & 4 & 36.25 & $\mathrm{AaBb}$ \\
\hline Segregating & Susceptible & 5 & 2 & 18.13 & Aabb \\
\hline Susceptible & Resistant & 0 & 1 & 9.06 & $\mathrm{aaBB}$ \\
\hline Susceptible & Segregating & 6 & 2 & 18.13 & $\mathrm{aaBb}$ \\
\hline Susceptible & Susceptible & 26 & 1 & 9.06 & aabb \\
\hline Total & $\ldots$ & 145 & 16 & 145.00 & $P<0.001$ \\
\hline
\end{tabular}

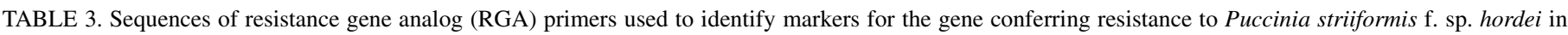
wheat cv. Lemhi

\begin{tabular}{|c|c|c|c|c|}
\hline RGA primer & Sequence $\left(5^{\prime}-3^{\prime}\right)^{\mathrm{a}}$ & Gene & Domain $^{b}$ & Reference \\
\hline AS1 & CAACGCTAGTGGCAATCC & $N, \operatorname{Rps} 2$ & P-loop & 24 \\
\hline AS3 & IAGIGCIAGIGGIAGICC & $N, \operatorname{Rps} 2$ & P-loop & 24 \\
\hline CLRR Rev & TAACGTCTATCGACTTCT & $C f 9$ & LRR & 9 \\
\hline Cre3Ploop & GCGGGTCTGGGAAATCTACC & Cre3 & P-loop & This study \\
\hline LM637 & ARIGCTARIGGIARICC & $L 6, N, \operatorname{Rps} 2$ & P-loop & 20 \\
\hline LM638 & GGIGGIGTIGGIAAIACIAC & L6, N, Rps 2 & P-loop & 20 \\
\hline NLRR Rev & TATAAAAAGTGCCGGACT & $N$ & LRR & 9 \\
\hline Pto kin2 & AGGGGGACCACCACGTAG & Pto & Kinase & 9 \\
\hline Pto kin3 & TAGTTCGGACGTTTACAT & Pto & Kinase & This study \\
\hline PtoFen-S & ATGGGAAGCAAGTATTCAAGGC & PtoFen & Kinase & This study \\
\hline RLK-For & GAYGTNAARCCIGARAA & LrK10 & Kinase & 18 \\
\hline RLRR Rev & ACACTGGTCCATGAGGTT & Rps 2 & LRR & 9 \\
\hline $\mathrm{S} 2$ & GGIGGIGTIGGIAAIACIAC & $N, R p s 2$ & P-loop & 24 \\
\hline S2-INV & CAICAIAAIGGITGIGGIGG & $N, \operatorname{Rps} 2$ & P-loop & This study \\
\hline XLRR For & CCGTTGGACAGGAAGGAG & $X a 21$ & LRR & 9 \\
\hline
\end{tabular}

a $\mathrm{I}=$ inosine and codes for mixed bases: $\mathrm{Y}=\mathrm{C} / \mathrm{T}, \mathrm{N}=\mathrm{A} / \mathrm{G} / \mathrm{C} / \mathrm{T}$, and $\mathrm{R}=\mathrm{A} / \mathrm{G}$.

${ }^{\mathrm{b}} \mathrm{LRR}=$ leucine-rich repeat and P-Loop $=$ phosphate binding loop. 
P. striiformis f. sp. hordei, it possesses a resistance gene for the formae speciales. The genes conferring resistance to the two formae speciales are different but closely linked. The results of this study also confirmed the previous report that $\operatorname{Yr} 21$ was on chromosome 1B (6). Further studies are needed to determine whether the Lemhi gene for resistance to P. striiformis f. sp. horde $i$ is in other wheat cultivars and if other wheat cultivars have different genes resistant to the inappropriate forma specialis.

In a similar study by Johnson and Lovell (19), resistance of Lemhi to an isolate of the barley-attacking form (BWR 80/1) was determined to be controlled by two dominant genes of major effect plus some other genes of smaller effect (minor genes), according to the segregation pattern for resistance and susceptibility in $\mathrm{F}_{3}$ and $\mathrm{F}_{4}$ generations in a cross between Lemhi and Chinese 166. Unlike genotype PI 478214, which is highly susceptible to all tested races of PSH (8), Chinese 166 often has intermediate reaction to barley stripe rust races $(8,41)$. In the study by Johnson and Lovell (19), IT readings were recorded at 10 to 14 days after inoculation; whereas, in this study, readings were taken at 18 and 21 days after inoculation. Thus, it is not possible to extrapolate the findings of the two studies. However, it is possible that Lemhi may contain additional genes conferring resistance to $P$. striiformis f. sp. hordei. In this study, only two PSH races were used. Virulence tests with additional PSH races may result in the detection of other resistance genes.

The results of this study indicate that a single dominant gene in wheat $\mathrm{cv}$. Lemhi is responsible for resistance to races of $P$. striiformis f. sp. hordei. This suggests the possible existence of a gene-for-gene relationship between wheat (inappropriate host) and $P$. striiformis f. sp. hordei. Reports of avirulence genes governing induction of resistance in nonhost species $(15,44,45)$ support the role of avirulence genes in determining disease reactions in nonhost species. In certain fungi, the formae speciales are closely related, leading to the exchange of genes between them

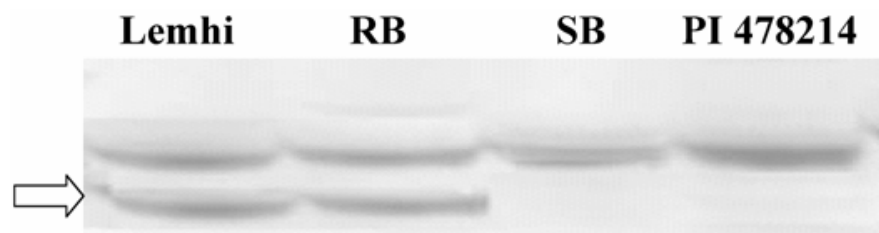

Fig. 1. Silver-stained denaturing polyacrylamide gel showing the resistance gene-analog polymorphism marker M7 amplified with primers S2-INV (5'CAICAIAAIGGITGIGGIGG-3') and AS3 (5'-IAGIGCIAGIGGIAGICC-3') in bulk segregant analysis with the resistant parent Lemhi, resistant bulk (RB), susceptible parent PI478214, and susceptible bulk (SB). causing overlap of host ranges (17), which is possible for $P$. striiformis f. sp. hordei and tritici with hosts wheat and barley. Thus, considering resistance to formae speciales, Niks (36) stated that it seems justifiable to assume that resistance to a forma specialis will, in many instances, not be essentially different from resistance to a pathogen species. Several plant pathosystems supporting this statement have been identified in which resistance to inappropriate formae speciales is governed by the gene-for-gene relationship leading to a hypersensitive response to the fungus

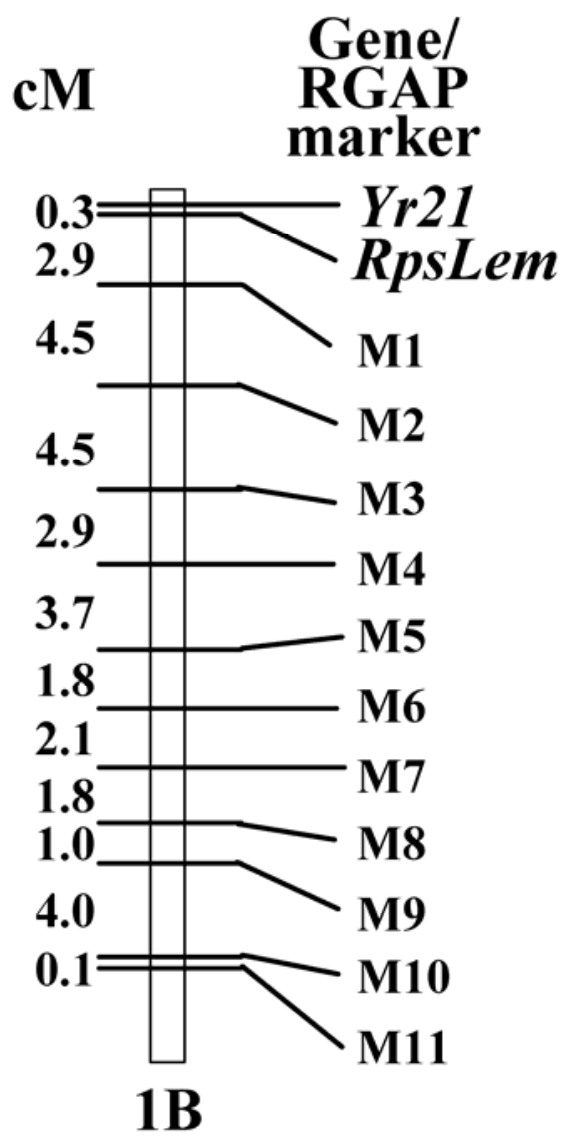

Fig. 3. Linkage map constructed for $Y r 21$ conferring resistance to race PST-21 of Puccinia striiformis f. sp. tritici and RpsLem for resistance to races PSH-14 and PSH-48 of $P$. striiformis f. sp. hordei with resistance gene analog polymorphism (RGAP) markers using the MAPMAKER version 3.0 (23). The linkage on chromosome $1 \mathrm{~B}$ was confirmed by analyzing the nullitetrasomic Chinese Spring lines with marker M10 that was linked in repulsion with the resistance allele in Lemhi.

\section{$F_{2}$ progeny}

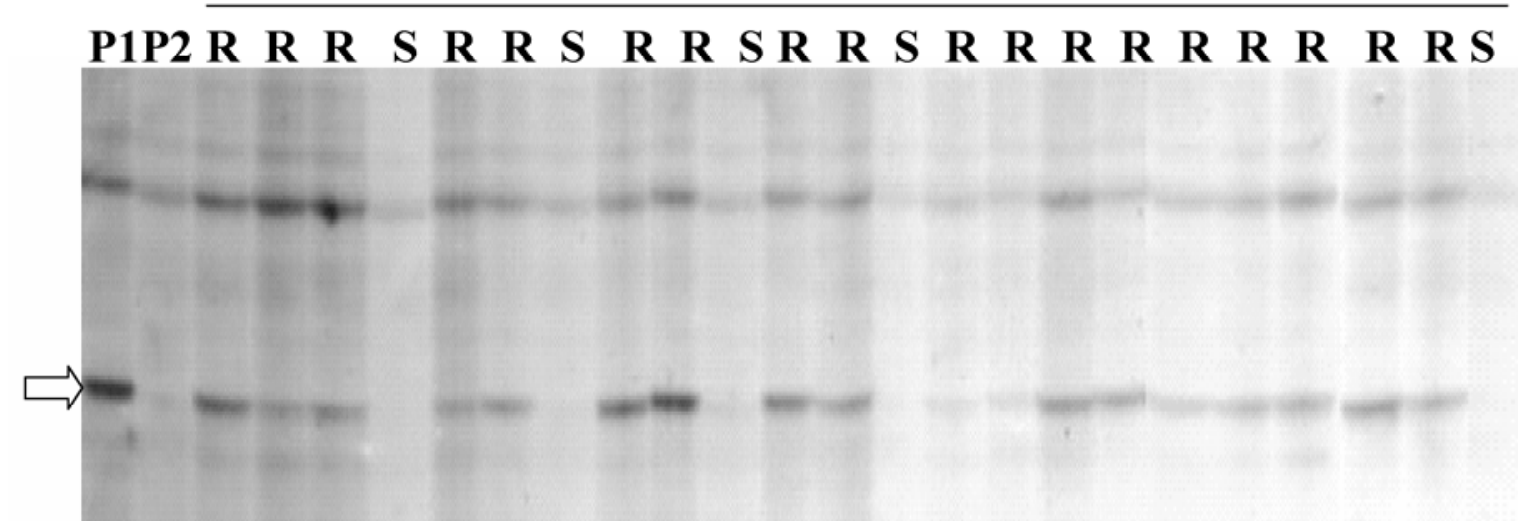

Fig. 2. Silver-stained denaturing polyacrylamide gel showing the resistance gene-analog polymorphism marker M5 amplified with Pto kin3 (5'-TAGTTCGGACGTTTACAT- $\left.3^{\prime}\right)$ and XLRR-For (5'-CCGTTGGACAGGAAGGAG- $\left.{ }^{\prime}\right)$ in analysis of $\mathrm{F}_{2}$ progeny. $\mathrm{R}=$ resistant, $\mathrm{S}=$ susceptible, and $\mathrm{L}=1$-kb-plus ladder. 
$(19,31,34,43)$. In a similar study with barley crosses, we found that barley resistance to $P$. striiformis f. sp. tritici also was under qualitative control (37). Although Lemhi is no longer a commercially important cultivar, its gene for resistance to $P$. striiformis f. sp. hordei may provide effective resistance when introgressed into barley cultivars. The molecular markers identified in this study should be useful in such introgression.

\section{ACKNOWLEDGMENTS}

We thank L. Carris and K. Campbell for valuable review and comments on the manuscript.

\section{LITERATURE CITED}

1. Chen, X. M., Hayes, P. M., Toojinda, T., Vivar, H., Kudrna, D., Kleinhofs, A., Leung, H., and Line, R. F. 1998. Genetic mapping of genes for stripe rust resistance in barley using resistance gene analog polymorphism and AFLP markers. (Abstr.) Phytopathology 88(suppl.):S16.

2. Chen, X. M., and Line, R. F. 1992. Inheritance of stripe rust resistance in wheat cultivars used to differentiate races of Puccinia striiformis in North America. Phytopathology 82:633-637.

3. Chen, X. M., and Line, R. F. 1999. Recessive genes for resistance to Puccinia striiformis f. sp. hordei in barley. Phytopathology 89:226-232.

4. Chen, X. M., and Line, R. F. 2001. Races of barley stripe rust in the United States. Barley Newsletter 44.

5. Chen, X. M., Line, R. F., Hayes, P. M., Toojinda, T., Vivar, H., Kleinhofs, A., and Kudrna, D. 1999. Mapping barley genes for resistance to stripe rust, leaf rust, and scab using resistance gene analog polymorphism and restriction fragment length polymorphism. (Abstr.) Phytopathology 89(suppl.):S15

6. Chen, X. M., Line, R. F., and Jones, S. S. 1995. Location of genes for stripe rust in spring wheat cultivars Compare, Fielder, Lee, and Lemhi and interactions of aneuploid wheats with races of Puccinia striiformis. Phytopathology 85:375-381.

7. Chen, X. M., Line, R. F., and Leung, H. 1993. Relationship between virulence variation and DNA polymorphism in Puccinia striiformis. Phytopathology 83:1489-1497.

8. Chen, X. M., Line, R. F., and Leung, H. 1995. Virulence and polymorphic DNA relationships of Puccinia striiformis f. sp. hordei to other rusts. Phytopathology 85:1335-1342.

9. Chen, X. M., Line, R. F., and Leung, H. 1998. Genome scanning for resistance gene analogs in rice, barley, and wheat by high-resolution electrophoresis. Theor. Appl. Genet. 97:345-355.

10. Chen, X. M., Line, R. F., Shi, Z. X., and Leung, H. 1998. Genetics of wheat resistance to stripe rust. Pages 237-239 in: Proc. Int. Wheat Genet. Symp. 9th. Vol. 3. A. E. Slinkard, ed. University Extension Press, University of Saskatchewan, Saskatoon, Canada.

11. Chen, X. M., and Moore, M. K. 2002. Epidemics and races of Puccinia striiformis in North America in 2001. (Abstr.) Phytopathology 92(suppl.):S14.

12. Chen, X. M., Moore, M. K., Milus, E. A., Long, D., Marshall, D., Line, R. F., and Jackson, L. 2002. Wheat stripe rust epidemics and races of Puccinia striiformis f. sp. tritici in the United States in 2000. Plant Dis. 86:39-46.

13. Chen, X. M., Moore, M. K., and Wood, D. A. 2003. Epidemics and control of stripe rust on spring wheat in the Pacific Northwest in 2002. (Abstr.) Phytopathology 93:S16.

14. de Vallavieille-Pope C., and Line, R. F. 1990. Virulence of North American and European races of Puccinia striiformis in North American, world, and European differential wheat cultivars. Plant Dis. 74:739-743.

15. de Wit, P. J. G. M. 1992. Molecular characterization of gene-for-gene systems in plant-fungus interactions and the application of avirulence genes in control of plant pathogens. Annu. Rev. Phytopathol. 30:391-418.

16. Eriksson, J. 1894. Uber die Spezialisierung des Parasitismus bei den Getreiderostpilzen. Ber. Dtsch. Bot. Ges. 12:292-331.

17. Eshed, N., and Dinoor, A. 1973. Genetic studies on the specialization of crown rust into pathogenic varieties (formae speciales). (Abstr.) Proc. 2nd Int. Congr. Plant Pathol. Minneapolis, MN.

18. Feuillet, C., Schachermayr, G., and Keller, B. 1997. Molecular cloning of a new receptor-like-kinase gene encoded at the $\mathrm{Lr} 10$ disease resistance locus of wheat. Plant J. 11:45-52.

19. Johnson, R., and Lovell, N. K. 1994. Genetics of resistance of wheat to barley-attacking races of Puccinia striiformis. Cereal Rusts Powdery Mildews Bull. 22:32-40

20. Kanazin, V., Marek, L. F., and Shoemaker, R. C. 1996. Resistance gene analogs are conserved and clustered in soybean. Proc. Natl. Acad. Sci.
USA 93:11746-11750.

21. Knott, D. R. 1961. The inheritance of rust resistance VI. The transfer of stem rust resistance from Agropyron elongatum to common wheat. Can. J. Plant Sci. 41:109-123.

22. Kosambi, D. D. 1944. The estimation of map distances from recombination values. Ann. Eugen. 12:172-175.

23. Lander, E. S., Green, P., Abrahamson, J., Barlow, A., Daly, J. M., Lincoln, S. E., and Newberg, L. 1987. Mapmaker: An interactive computer package for constructing primary genetic linkage maps of experimental and natural populations. Genomics 1:174-181.

24. Leister, D., Ballvora, A., Salamini, F., and Gebhardt, C. 1996. A PCRbased approach for isolating pathogen resistance genes from potato with potential for wide application in plants. Nat. Genet. 14:421-429.

25. Line, R. F. 2002. Stripe rust of wheat and barley in North America: A retrospective historical review. Annu. Rev. Phytopathol. 40:75-118.

26. Line, R. F., and Chen, X. M. 1995. Success in breeding for and managing durable resistance to wheat rusts. Plant Dis. 79:1254-1255.

27. Line, R. F., and Chen, X. M. 1996. Wheat and barley stripe rust in North America. Pages 101-104 in: Proc. 9th Eur. Mediterr. Cereal Rusts Powdery Mildews Conf. Lunteren, The Netherlands.

28. Line, R. F., Konzak, C. F., and Allan, R. E. 1974. Evaluating resistance to Puccinia striiformis in induced mutations for disease resistance in crop plants. International Atomic Energy Agency, Vienna. IAEA 180:125-132.

29. Line, R. F., and Qayoum, A. 1992. Virulence, aggressiveness, evolution, and distribution of races of Puccinia striiformis (the cause of stripe of wheat) in North America, 1968-1987. U. S. Dep. Agric. Bull. 1788.

30. Maniatis, T. A., Frisch, E. F., and Sambrook, J. 1982. Molecular Cloning: A Laboratory Manual. Cold Spring Harbor Laboratory, Cold Spring Harbor, NY.

31. Matsumura, K., and Tosa, Y., 1995. The rye mildew fungus carries avirulence genes corresponding to wheat genes for resistance to races of the wheat mildew fungus. Phytopathology 85:753-756.

32. McIntosh, R. A. 1992. Pre-emptive breeding to control wheat rusts. Euphytica 63:103-113.

33. McIntosh, R. A., Hart, G. E., Devos, K. M., Gale, M. D., and Rogers, W. J. 1998. Catalogue of gene symbols for wheat. Pages 1-235 in: Proc. 9th Int. Wheat Genet. Symp. A. E. Slinkard, ed. University Extension Press, University of Saskatchewan, Saskatoon, Canada.

34. Neu, C., Keller, B., and Feuillet, C. 2003. Cytological and molecular analysis of the Hordeum vulgare-Puccinia triticina nonhost interaction. Mol. Plant-Microbe Interact. 16:626-633.

35. Newton, A. C., Johnson, R., and Caten, C. E. 1985. Isozyme and dsRNA analysis in isolates of three cereal rust species. Plant Pathol. 34:235-247.

36. Niks, R. E. 1987. Nonhost plant species as donors for resistance to pathogens with narrow host range. I. Determination of nonhost status. Euphytica 36:841-852.

37. Pahalawatta, V., and Chen, X. M. 2004. Inheritance of and molecular mapping of wheat and barley genes for resistance to inappropriate formae speciales of Puccinia striiformis. (Abstr.) Phytopathology 94(suppl.):S80.

38. Riede, C. R., and Anderson, J. A. 1996. Linkage of RFLP markers to an aluminum tolerance gene in wheat. Crop Sci. 36:905-909.

39. Roelfs, A. P., Huerta-Espino, J., and Marshall, D. 1992. Barley stripe rust in Texas. Plant Dis. 76:538.

40. Shi, Z. X., Chen, X. M., Line, R. F., Leung, H., and Wellings, C. R. 2001. Development of resistance gene analog polymorphism markers for the $\operatorname{Yr} 9$ gene resistance to wheat stripe rust. Genome 44:509-516.

41. Stubbs, R. W. 1985. Stripe rust. Pages 61-101 in: The Cereal Rusts. Vol. 2, Disease, Distribution, Epidemiology and Control. A. P. Roelfs and W. R. Bushnell, eds. Academic Press, Orlando, FL.

42. Toojinda, T., Broers, L., Chen, X. M., Hayes, P. M., Kleinhofs, A., Korte, J., Kudrna, D., Leung, H., Line, R. F., Powell, W., and Vivar, H. 2000. Mapping qualitative and quantitative disease resistance genes in a doubled haploid population of barley (Hordeum vulgare). Theor. Appl. Genet. 101:580-589.

43. Tosa, Y., Tsujimoto, H., and Ogura, H. 1987. A gene involved in the resistance of wheat to wheatgrass powdery mildew fungus. Genome 29:850-852.

44. Van't Slot, K. A. E., and Knogge, W. 2002. A dual role for microbial pathogen-derived effector proteins in plant disease and resistance. Crit. Rev. Plant Sci. 21:229-271.

45. Whalen, M. C., Stall, R. E., and Staskawicz, B. J. 1988. Characterization of a gene from a tomato pathogen determining hypersensitive resistance in nonhost species and genetic analysis of this resistance in bean. Proc. Natl. Acad. Sci. USA 85:6743-6747.

46. Yan, G. P., Chen, X. M., Line, R. F., and Wellings, C. R. 2003. Resistance gene-analog polymorphism markers co-segregating with the $\operatorname{Yr} 5$ gene for resistance to wheat stripe rust. Theor. Appl. Genet. 106:636-643.

47. Yu, Y. G., Buss, G. R., and Maroof, M. A. 1996. Isolation of a superfamily of candidate disease resistance genes in soybean based on a conserved nucleotide-binding site. Proc. Natl. Acad. Sci. USA 93:11751-11756. 